\title{
1: 109942484-109948409
}

National Cancer Institute

\section{Source}

National Cancer Institute. 1: 109942484-109948409. NCI Thesaurus. Code C42431.

Physical location of GSTM1_Gene 